\title{
MANAGING ENGLISH COMPETENCE AS A COMPETITIVE ADVANTAGE: CASE STUDY AT STES ISLAMIC VILLAGE TANGERANG
}

\author{
Muizzudin, \\ Sekolah Tinggi Ekonomi Syariah Islamic Village \\ Email: muizviva@gmail.com.
}

\begin{abstract}
The purpose of this research is to know the level of English competence the students of the seventh semester at STES Islamic Village Tangerang in the academic year of 2018-2019. The instrument of this research is TOEFL paper-based test called TOEFL Prediction. The result of this research showed out of forty students only one student (2.5\%) achieved the minimum score required by the institution. Most of them $(97.5 \%)$ could not reach the minimum score. Although this is still the initial step to manage English competence as a competitive advantage for STES Islamic Village Tangerang. The research result will lead to the necessity of follow-up research to do so.
\end{abstract}

Keywords : Competence, competitive, advantage, TOEFL.

\section{INTRODUCTION}

Mastering English competence is very important for students. It will absolutely give them a lot of benefits when they are still students and also when they graduate. When they are still in college, mastering English competence can signficantly help them have better Grade Point Average (GPA) but also offer opportunities to develop themselves optimally. They can broaden knowledge and horizon since they can browse supporting references in English, actualize themselves by actively participating in international seminars, conferences discussion, English speech competition, English debate competition, essay writing competition, student mobility program, student exchange program, etc.

Students with good command of English will have better career and better future after they finish their studies. If they prefer to be entrepreneurs or run non profit organizations, they will be provided brighter opportunities on the national and international scopes. If they want to work for a state-owned company, local government-owned company, government, or private companies, mastering English will definitely give them pluses over the others. They can easily meet the language competence mastery in the recruitment and promotion because they can achieve a certain score of TOEFL as one of the requirments. Alumni with good command of English will have a chance to continue their studies in Indonesia or abroad. They also can get scholarship easily as they can obtain a minimun score of TOEFL or IELTS as one of the requirments within their capabilities.

In the level of the institution, the mastery of English students can achieve can have a positive impact. It can even be a force of a competitive advantage since it can build good reputation and escalate the trust from the people, business community, government, and other stake holders. This condition has a positive correlation with the growth of the institution. The institution will have more students, chance of model institution with good English learning, achievable access to reputable univiersities or educational or non educational institutions abroad to run collaborations. 
Overal, the mastery of English will provide a competitive advantage to the institution as long as it can manage the students intakes, process, and outcomes well..

\section{Formulating The Problems Of The Research}

The problems of the research are defined as follows:

1. What is the level of English competence students of the seventh semester achieve?

2. Should STES Islamic Village establish control system of managing English competence?

3. Should STES Islamic Village apply competitive advantage in managing English competence?

\section{Establishig control system of Managing English Competence}

Managing English competence of STES students requires the application of control system called the four-step process of control: establishing performance standards, measuring the actual performance, comparing actual performance to the standards, and taking corrective action (Allison Tanner, 2019).

The first step, establishing performance standards, refers to a certain score of TOEFL paper-based test. Theoritically and practically, it requires harmonizing the realistic and ideal targets. Failing to do so will result in the incapability of making English competence students achieve the drivig force of the competitive advantage. Harmonizing the realistic and ideal targets will lead to the neccesity of fulfilling the signifacant factors on one hand and eploring the available references of the ideal targeted score of TOEFL students should have. The signifacant factors that need to be fulfilled include six items: First, the factual average of English competence students achieve; Second, length of studies available; Third, learning media such as books, audio, video, and visual system in the class; Fourth, teaching skills lecturers master; Fifth, learning behavior; Sixth, test instrument. The available references of the ideal targeted score of TOEFL can be taken from at least four sources: First, the expected score of undergraduate students in reputable universities; Second, the minimum score required for the new employee recrutment; Third, the required minimum score of Indonesian people who want to get scholarship to study abroad; Fourth, the average score of Indonesian people who took TOEFL test. The expected score of undergraduate students in reputable universities is varied. Just take a look at UIN Jakarta for example. It requires 450 for brand new students of non English language study program and 500 for brand new students of English language study program (UIN Jakarta, 2018). The minimum score required for government employee recrutment ranges from 450 to 500 (MelaArnani, 2018). The required minimum score of Indonesian people who want to get scholarship to study abroad is 550 for master's degree (RedaksiKumparan, 2017). The average score of Indonesian people who took TOEFL test is 500 TOEFL Paper-based test and 85 TOEFL Internet'based test (Educational Testing Service, 2018).

The second step, measuring the actual performance, needs the test instrument that is structured, reliable, and easy to use, that is TOEFL ITP or TOEFL Prediction. It also needs the classification of the level of English competence students can achieve. There are eight levels of English competence: First, Post-advanced with the score of > 526; Second, Advanced with the score of 501-525; Third, Pre-advanced with the score of 476-500; Fourth, Intermediate with the score of 451-475; Fifth, Pre-intermediate with the score of 426-450; Sixth, Elementary with 
the score of 401-425; Seventh, Pre-elementary with the score of 351-400; Eighth, Real beginner with the score of 300-350 (SofendiSofendi, 2011).

The third, comparing actual performance to the standards means that the actual score of TOEFL students achieve is compared to the standard set and symbolized the harmonized realistic and ideal targeted score of TOEFL.

The fourth, taking corrective action covers evaluating and reevaluating the signifacant factors mentioned about, namely the factual average of English competence students achieve, length of studies available, learning media such as books, audio, video, and visual system in the class, teaching skills lecturers master, and the test instrument.

\section{Setting A Competitive Advantage}

Historically, the concept of the competitive advantage is for the companies or profitoriented organizations. However, educational institutions also can adopt the concept of competitive advantage by adjusting the terminology used. A competitive advantage is defined as the increased rate of attractiveness a firm offers compared to competitors from customers' viewpoin(Akram Sadat Hosseini et al, 2018). According to the above definitions of competitive advantage, it seems that a direct relation between students and their parents as customers' expected values, values offered by the institution, and those offered by the competitors determine the dimensions and conditions of competitive advantage. If the values presented by the institution are closer to customers' expected values compared to the values offered by competitors, it can be said that the institution has competitive advantage over its competitors in one or more indices. This advantage makes the institution superior to its competitors in proximity to customers and capturing his heart.

\section{METHODOLOGY}

The methodology used in this research is descriptive qualitative, that is, showing and describing scores of TOEFL Paper-based test (TOEFL Prediction) all of the students of the sixth semester in two majors Sharia Economics and Sharia Banking at STES Islamic Village achieved in the academic year of 2018-2019. The TOEFL Prediction consists of three sections: listening comprehension, structure, and reading comprehension. The population is 40 students. The scores are mapped in order to show the descriptive quantitative data of levels of English competence and explore the answers to two research questions above.

\section{FINDINGS AND DISCUSSION}

The participants of the TOEFL Prediction the students of the sixth semester in two majors Sharia Economics and Sharia Banking at STES Islamic Village are shown in the following table.

Tabel 1: The participants of TOEFL Prediction

\begin{tabular}{|c|c|c|c|}
\hline NO. & MAJORS AND CLASSES & NUMBER & $\%$ \\
\hline 1 & Sharia Economics Morning Class & 14 & 35 \\
\hline 2 & Sharia Banking Morning Class & 3 & 7.5 \\
\hline 3 & Sharia Economics Evening Class & 17 & 42.5 \\
\hline 4 & Sharia Banking Evening Class & 6 & 15 \\
\hline & TOTAL & 40 & 100 \\
\hline
\end{tabular}

Source: Primary Data

Online available : http://jurnal.stesislamicvillage.ac.id/index.php/JURNAL 
The scores of TOEFL Prediction the students of the sixth semester in two majors Sharia Economics and Sharia Banking at STES Islamic Village achieved in the two academic year of 2018-201 are shown in the following table.

Tabel 2: Score Recapitulation of TOEFL Prediction

\begin{tabular}{|c|l|c|c|c|}
\hline \multirow{2}{*}{ NO. } & \multicolumn{1}{|c|}{ Majors And Classes } & \multicolumn{2}{|c|}{ Score Ranges } & \multirow{2}{*}{ Average } \\
\cline { 3 - 4 } & & The Highest & The Lowest & \\
\hline 1 & Sharia Economics Morning Class & 400 & 313 & 358 \\
\hline 2 & Sharia Banking Morning Class & 367 & 317 & 343 \\
\hline 3 & Sharia Economics Evening Class & 473 & 297 & 372 \\
\hline 4 & Sharia Banking Evening Class & 410 & 327 & 356 \\
\hline
\end{tabular}

Source: Primary Data

Tabel 3: Levels of English Competence

\begin{tabular}{|c|l|c|c|}
\hline NO. & \multicolumn{1}{|c|}{ LEVELS OF ENGLISH COMPETENCE } & NUMBER & $\%$ \\
\hline 1 & Post-advanced ( > 526) & 0 & 0 \\
\hline 2 & Advanced (501-525) & 0 & 0 \\
\hline 3 & Pre-advanced (476-500) & 0 & 0 \\
\hline 4 & Intermediate (451-475) & 1 & 2.5 \\
\hline 5 & Pre-intermediate (426-450) & 2 & 2.5 \\
\hline 6 & Elementary (401-425) & 18 & 5 \\
\hline 7 & Pre-elementary (351-400) & 18 & 45 \\
\hline 8 & Real beginner (300-350) & 40 & 45 \\
\hline & \multicolumn{2}{|c|}{ TOTAL } & \\
\hline
\end{tabular}

Source: Primary Data

As it is written in the statue of STES Islamic Village, the required minimum score of TOEFL is 450 . There is only one student who has fulfilled the required minimum. If the students are pushed to jump to achieve the required minimum score, it is statically, theoritically, and practically impossible to do so since the gap is too broad.

Based on the data collected, there is a call for establishing control system of managing English competence. As it is mentioned in control system called the four-step process of control, there should be a corrective action taken in terms of length of studies available, teaching skills lecturers master, and learning behavior.

Also, there is a need for STES Islamic Village to apply competitive advantage in managing English competence.

\section{CONCLUSION}

From the descriptive qualitative research shown, the following is the conclusion:

1. The English competence students of the seventh semester achieve is too far beyond the targeted score of TOEFL as mentioned in the institutional statute, that is 450 .

2. Following eight levels of English competence based on the TOEFL score, the level of English competence the students achieved is really not ideal. No one is in level of postadvanced ( > 526), advanced (501-525), pre-advanced (476-500). There is only one student in the level of intermediate (451-475). There is only one student in the level of pre-

Online available : http://jurnal.stesislamicvillage.ac.id/index.php/JURNAL 
intermediate (426-450). There are only two students in the level of elementary (401-425). There are eighteen students in the level of pre-elementary (351-400). There are eighteen students in the level of real beginner (300-350).

3. Since there is a huge gap between the actual scores the students achieved and the required minimum TOEFL score, STES Islamic Village should establish control system of managing English competence.

To hold a good positioning, STES Islamic Village should apply competitive advantage in managing English competence following the application of control system.

\section{IMPLICATION}

Based on the mapping of the TOEFL score obtained, it is possible to summarize that corrective action should be taken from the very beginning. Harmonizing the real and the ideal TOEFL score the students should achieve must be taken into consideration.

\section{LIMITATIONS AND SUGGESTIONS}

The descriptive qualitative research in the form of mapping the TOEFL scores the students obtained is only the first step to manage English competence as a competitive advantage. There should be follow-up research both qualitative and quantitative to improve the quality of the TOEFL scores the students should obtain such as the research on the length of studies needed, the learning behavior, the teaching skills, the learning and teaching media, etc. 


\section{BIBLIOGRAPHY}

Akram Sadat Hosseini et al. (2018). Competitive Advantage and Its Impact on New Product Development Strategy. Diambildari https://www.google.com/url?sa=t\&rct=j\&q=\&esrc=s\&source=web\&cd=3\&ved=2ahUKEwjZv PiU1rLiAhVadCsKHXfaDbwQFjACegQIARAC\&url=https\%3A\%2F\%2Fwww.mdpi.com\%2F 2199-8531\%2F4\%2F2\%2F17\%2Fpdf\&usg=AOvVaw3_y4pRoquFCNndUEdGL9g3

Allison Tanner. (2019). Control System: The Four-Step Process. Diambildari https://study.com/academy/lesson/control-system-the-four-step-process.html

Educational Testing Service. (2018). Test and Score Data Summary for the TOEFL iBT® Tests. Diambildari https://www.ets.org/s/toefl/pdf/94227_unlweb.pdf

MelaArnani. (2018, September 20). Ini 6 Kementerian/Lembaga yang Syaratkan TOEFL bagiPelamar CPNS 2018. Koran Kompas. Diambildari https://nasional.kompas.com/read/2018/09/20/12555931/ini-6-kementerianlembaga-yangsyaratkan-toefl-bagi-pelamar-cpns-2018?page=all

RedaksiKumparan. (2017, Februari 6). SyaratBisaDapatBeasiswa LPDP: IPK Minimal 3,0dan TOEFL 550. Kumparan. Diambildari https://kumparan.com/@ kumparannews/syarat-bisadapat-beasiswa-lpdp-ipk-minimal-3-0-dan-toefl-550

SofendiSofendi. (2011). English Mastery Of Students Of Engineering Faculty, Sriwijaya University Academic Year 2010/2011. 3(5). Diambildari https://scholar.google.co.id/scholar?oi=bibs\&cluster=12066660597872940088\&btnI=1\&hl=id

UIN Jakarta. (2018). MabaWajibTesKemampuanBerbahasaAsing. Diambildari UIN Jakarta website: https://www.uinjkt.ac.id/id/maba-wajib-tes-kemampuan-berbahasa-asing/ 